\title{
A INTERDISCIPLINARIDADE DA RETÓRICA E SUA INFLUÊNCIA NA MÚSICA COLONIAL BRASILEIRA
}

\author{
Eliel Almeida Soares ${ }^{1}$ \\ Rubens Russomanno Ricciardi ${ }^{2}$
}

Resumo: Em determinadas músicas do final do século XVI ao começo do século XIX, a retórica mostrou-se como componente indispensável à tarefa de compreender e clarificar o discurso musical, haja vista a sua utilização, relacionada à gramática, bem como sua adequação nas estruturas musicais. Tal processo ocorreu por meio de uma sistematização e teorizaçáo aprimorada por diversos tratadistas da retórica musical, cujo postulado se embasava nos mestres da Retórica Clássica, Aristóteles, Cícero e Quintiliano, estabelecendo, assim, uma nomenclatura conhecida como Musica Poetica. Resultantes dessa metodização, vários tratados destacavam os meios pelos quais a música pudesse ser elaborada num discurso organizado e ordenado por elementos retóricos, de modo a mover os afetos do ouvinte. Nesse sentido, nos últimos 50 anos, a área da Música, através da musicologia, da performance e da teoria-análise, vem demonstrando interesse sobre o tema, desenvolvendo inúmeras pesquisas mediante análise retórico-musical, objetivadas em esclarecer a relação entre música e afeto. Por esse motivo, este artigo apresenta o diálogo da retórica com as outras áreas do conhecimento humano, a saber, Música, Filosofia e Hermenêutica, além da sua influência e emprego na música colonial brasileira por alguns compositores.

Palavras-chave: Retórica. Filosofia e hermenêutica. Música colonial brasileira. Compositores brasileiros.

${ }_{1}$ Pós-doutorando em Música pela Faculdade de Filosofia, Ciências e Letras de Ribeirão Preto da Universidade de São Paulo (FFCLRP-USP), Ribeirão Preto, SP - Brasil.

(D) https://orcid.org/ 0000-0001-6351-6694. E-mail: eliel.soares@usp.br.

2 Professor Titular do Departamento de Música da Faculdade de Filosofia, Ciências e Letras de Ribeirão Preto da Universidade de Sáo Paulo (FFCLRP-USP), Ribeirão Preto, SP - Brasil.

(D) https://orcid.org/0000-0002-6895-2177. E-mail: rubensricciardi@gmail.com.

https://doi.org/10.1590/0101-3173.2021.v44n4.13.p157

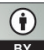

This is an open-access article distributed under the terms of the Creative Commons Attribution License. 


\section{INTRODUÇÁOO}

Sendo uma das disciplinas humanas mais antigas, a retórica, semelhantemente à gramática, à lógica e à poética, é discutida, pesquisada, estudada e definida de vários modos. Por exemplo, Edward P. J. Corbett (19191998) (2005) assevera que, para Aristóteles (384-322 a. C.), a retórica náo seria simplesmente um mero produto idealizado de princípios combinados em persuadir ou convencer outras pessoas. Seria, de fato, um constructo elaborado, pautado e embasado na experiência de hábeis oradores. Em outras palavras:

$\mathrm{Na}$ formação e estruturação resultante da análise das suas estratégias, na codificação de preceitos advindos da experiência com a finalidade de auxiliar os praticantes da oratória a exercitarem-se de maneira correta, sobre as diversas técnicas de persuasão. (ALEXANDRE JÚNIOR, 2005, p. 16, introdução).

Por sua vez, conforme Rubén López Cano (2000, p. 21), Marco Túlio Cícero (106-43 a.C.) argumenta que, no discurso retórico, "[...] é importante que o orador mostre domínio e habilidade para convencer e persuadir o ouvinte." Ou seja, um bom orador é aquele que tem a capacidade de mover as emoçôes de quem o escuta.

Já Marco Fábio Quintiliano (35-95), em sua Instituo Oratoria (ca.95), apresenta um quadro comparativo acerca da natureza retórica e de suas definições, por quatro convenções clássicas:

Quadro 1 - Definiçóes sobre Retórica, segundo Quintiliano.

- Causadora e geradora de persuasão, segundo Córax, Tísias, Górgias e Platão;

- Onde são descobertas as formas de persuasão relativas a um dado assunto, segundo Aristóteles;

- A faculdade de falar bem, no que concerne aos assuntos públicos, segundo Hermágoras;

- A ciência de bem-falar, de acordo com o próprio Quintiliano. Fonte: QUINTILIANO, Ist. Or., II, XV, \$-1-38, 1720, p. 178-185, passim. 
Outra definição localizada em Plebe (1978, p. 17) é a de Plutarco (46120), o qual assim concebe a retórica:

É a arte relativa aos discursos, que tem sua força no ser artífice de uma persuasão, nos discursos políticos sobre todos os assuntos, arte essa criadora de uma crença e não de ensinamentos. Os seus argumentos próprios dizem respeito, sobretudo, ao justo e ao injusto, ao bem e ao mal, ao belo, e ao feio.

Examinando outras definiçóes, pôde-se constatar que a retórica é indispensável para a elaboração de uma argumentação, tese, propositura e discurso. Além disso, ela é um saber que pode ser associado a outras áreas do conhecimento humano, as quais serão expostas em alguns exemplos abaixo.

Rafael Bluteau (1638-1734) define a retórica como "[a] arte de falar com propriedade e elegância, inculcando boas razôes, para provar e persuadir os ouvintes.” (1720, p. 305). Helena Beristáin (1927-2013) salienta que retórica "[...] é a arte de elaborar discursos gramaticalmente corretos, elegantes e, sobretudo, persuasivos." (1995, p. 421). Nicola Abbagnano (1901-1990) apresenta a retórica como "[...] arte de persuadir com o uso de instrumentos linguísticos.” (1998, p. 856; 2007, p. 856).

Oliver Reboul (1925-1992) afirma que a “[...] retórica é a arte de persuadir pelo discurso," (2004, p. XIV). Na mesma linha de raciocínio, Antônio Houaiss (1916-1999) a conceitua como "[...] conjunto de regras que constitui a arte do bem-dizer, arte da eloquência, oratória e, por extensão, também, o conjunto de regras que consistem e organizam a nossa arte." (2001, p. 2447).

No que lhe concerne, Aurélio Buarque de Holanda Ferreira (19101989) descreve-a como "[...] a capacidade de pôr em prática uma ideia através de estudo do uso persuasivo da linguagem, em especial para o treinamento de oradores." (FERREIRA, 2004, p. 1751).

Finalmente, Chaïm Perelman (1912-1984) expõe que a retórica

[...] é a arte de falar em público de maneira convincente, em outras palavras, o objeto da retórica desde a Antiguidade Clássica era, acima de tudo, a obtenção da adesão favorável dos ouvintes mediante a tese apresentada pelo orador. (PERELMAN, 2005, p. 6). 
Por esse motivo, segundo Manuel Alexandre Júnior (2005), que fez a introdução e é um dos tradutores do livro Retórica, de Aristóteles, fazer uma definição sobre retórica é trabalhosa, por alguns motivos:

1. Pelo fato de nunca ter havido um sistema uniforme preciso;

2. Ela sempre se apresentou como disciplina flexível;

3. Ela é mais preocupada com a persuasão dos ouvintes do que com a produção de formas de discurso;

4. Sua preocupação é mais manifesta com a função retórica do que com a composição ou estrutura do próprio texto.

Todavia, todas essas descrições e definiçôes concordam em um aspecto: que a retórica e o seu estudo têm como objetivo a criação e a produção de discursos com propósitos persuasivos. Embora idênticas no essencial, elas enfatizam quatro elementos retóricos relevantes, conforme realça Alexandre Júnior (2005, p. 24, introdução):

1. O seu estado metodológico, ou seja, um conhecimento organizado num sistema ou método, com a finalidade de atingir um determinado objetivo prático;

2. O seu propósito, que trata da finalidade do discurso, ou seja, dos oradores;

3. O seu objeto, que visa à prática na oratória, em um horizonte retórico de três gêneros de discurso público: judicial, deliberativo e epidíctico;

4. O seu conteúdo ético, a neutralidade.

Sob o exame dessas ponderaçôes e consideraçôes, pode-se perceber que a retórica, desde a Antiguidade greco-romana, permeando diversas épocas e chegando à contemporaneidade, tem sido mecanismo usual e objeto de estudo que abarca vários campos do conhecimento. Em outras palavras, a retórica requer do pesquisador uma investigação mais aprofundada, não somente da história, mas também de contextos filosóficos, políticos, sociais e estéticos. De acordo com Alexandre Júnior (2005, p. 9, introdução), para alguns, 
[...] a retórica seria mera manipulação linguística, ornato estilístico e discurso, servindo-se de artifícios psicológicos, mais interessados à verbalização de discursos vazios de conteúdo do que fundamentados em princípios e valores que se nutrem de um raciocínio crítico, válido e eficaz. Contudo, seu restabelecimento, enquanto antigo estatuto de teoria e prática da argumentação persuasiva, a retórica vem sendo novamente valorizada como uma área do conhecimento humano, operando tanto na heurística como na hermenêutica dos dados interventores no discurso.

A retórica, desse modo, como realça Alexandre Júnior (2005), é um saber que se inspira em vários saberes, reciprocamente se colocando para servir a todos eles. É um conhecimento multidisciplinar no sentido pleno da palavra, na medida em que se afirmou como arte de pensar e arte de comunicar o pensamento. Assim, como tal, pode se multiplicar em interdisciplinar e transdisciplinar, pois ela está presente no direito, na filosofia, na oratória, na dialética, na literatura, na hermenêutica, na crítica literária, nas ciência e nas artes, de modo geral.

Tais atribuiçôes se mostram essenciais para a elaboração de um discurso, sendo a retórica um mecanismo instigante, que auxilia o orador em convencer o público favoravelmente à sua tese, seja por meio da dialética, seja como ressaltam Hilton Japiassú e Danilo Marcondes (2001, p. 235), “[...] por sua habilidade em empregar a linguagem como recurso de persuasão e eloquência, com o propósito de despertar os afetos do ouvinte."

Para tanto, tal como se observa em Soares, Novaes e Machado Neto (2012a), emprega-se uma variedade de artifícios metafóricos, alegóricos e analógicos, os quais podem ser verificados em diversos teóricos, filósofos, tratadistas e autores, em que, desde a Antiguidade greco-romana, se estabeleciam conceitos perceptíveis entre si. No mesmo sentido, os compositores do final do século XVI ao início do século XIX utilizavam, em determinadas obras, elementos retóricos, almejando, assim, clarificar tanto o enunciado quanto a disposição do discurso musical.

Além disso, esses preceitos retóricos, além do emprego de uma linguagem figurativa, são examináveis na música colonial brasileira, em certos autores, como Manuel Dias de Oliveira (? - 1734/35 - Vila de São José, 1813), José Joaquim Emerico Lobo de Mesquita (? - 17?? - Rio de Janeiro, 1805)

\footnotetext{
${ }^{3}$ Alguns autores datam seu nascimento em 1746. No entanto, de acordo com Francisco Curt Lange (1903-1997), “[...] não há registro preciso da data de seu nascimento." (1983, p. 113).
} 
André da Silva Gomes (Lisboa, 1752 - São Paulo, 1844) e José Maurício Nunes Garcia (Rio de Janeiro, 1767-1830).

Nessa perspectiva, as áreas da musicologia, da teoria-análise e da performance musical, nos últimos 50 anos, vêm demonstrando interesse sobre essa disciplina relacionada à música dos séculos supracitados. Contudo, é pertinente destacar que a maioria das investigaçóes se concentra em compositores barrocos e nos princípios do Classicismo não brasileiros. Por essa razão, este artigo visa a expor o exame da própria retórica com sua diversidade de gamas organizacionais e epistemologias, no discurso musical, além do diálogo da retórica com as outras áreas do conhecimento humano, a saber, música, filosofia e hermenêutica, examinando sua influência e emprego, na música colonial brasileira, por alguns compositores.

\section{OS COMPONENTES RETÓRICOS E SUAS UTILIDADES}

Alexandre Júnior (2005, p. 37, introdução) assinala que, desde a Retórica de Aristóteles, se observa que os meios artísticos de persuasão são três:

1. Os derivados do caráter do orador $\tilde{\eta} \theta 0 \varsigma$ (éthos);

2. Os derivados da emoção despertada pelo orador nos ouvintes $\pi \alpha ́ \theta 0 \varsigma$ (páthos);

3. Os derivados de argumentos verdadeiros ou prováveis $\lambda$ ó $\gamma \circ$ (lógos).

Aristóteles (Ret., I, 1355a, 2005, p. 92-93) enfatiza que esses três elementos auxiliam o raciocínio entimemático, pois, para ele, o verossímil é a verdade no campo retórico, logo, nesse setor, ambas têm concepçóes semelhantes:

Ora, sendo evidente que o método artístico é o que se refere às provas por persuasão e que a prova é uma espécie de demonstração (pois somos persuadidos sobretudo quando entendemos que algo está demonstrado), que a demonstração retórica é o entimema e que este é, geralmente falando, a mais decisiva de todas as provas por persuasão; que, enfim, o entimema é uma espécie de silogismo ${ }^{4}$, e que é do silogismo em todas as suas variantes que se ocupa a dialética, no seu todo ou em algumas das partes, e é igualmente evidente que quem melhor poder teorizar sobre as premissas do que e como se ${ }^{4}[$ Do gr. $\sigma 0 \lambda \lambda \sigma \gamma 1 \sigma \mu$ ó $\{$ syllogismós\}, "argumento", pelo lat. syllogismus]. Dedução formal tal que, postas
duas proposiçóes, chamadas premissas, delas, por inferência, tira-se uma terceira, chamada conclusão. 
produz um silogismo também será o mais hábil em entimemas, porque sabe a que matérias se aplica o entimema e que diferenças este tem dos silogismos lógicos. Pois, é próprio de uma mesma faculdade discernir o verdadeiro e o verossímil, já que os homens têm uma inclinação natural para a verdade e a maior parte das vezes alcançam-na. E, por isso, ser capaz de discernir sobre o plausível é ser igualmente capaz de discernir sobre a verdade.

Portanto, como acentuado pelo filósofo, teórico e tratadista grego, as provas de persuasão proporcionadas pelo discurso são de três espécies, as quais serão apresentadas a seguir.

\section{1 ÉTHOS}

Aristóteles (2005) ressalta que é mediante o caráter honesto do orador que se pode obter maior persuasão e eficácia, no discurso proferido. Em outras palavras, aquele que faz a elocução perante o público deve ser transparente, tanto em seu pronunciamento quanto em sua conduta moral e ética:

Persuade-se pelo caráter quando o discurso é proferido de tal maneira que deixa a impressão de o orador ser digno de fé. Pois, acreditamos mais e bem mais depressa em pessoas honestas, em todas as coisas em geral, mas sobretudo nas de que não há conhecimento exato e que deixam margem para dúvida. É, porém, necessário que esta confiança seja resultado do discurso e não de uma opiniáo prévia sobre o caráter do orador; pois náo se deve considerar sem importância para a persuasão e probidade do que fala, como, aliás alguns autores desta arte propóem, mas quase se podia dizer que o caráter é o principal meio de persuasão. (ARISTÓTELES, Ret., I, 1356a, 2005, p. 96).

No mesmo sentido, Quintiliano (Inst. Or., VI, 2, 1720, p. 519, tradução nossa) destaca que, no éthos, os oradores devem procurar deixar claras e evidentes, em seu discurso, suas qualidades morais:

O éthos, que nós compreendemos e que demanda dos oradores, é esse sentimento que vai ser avaliável por sua pura bondade, suave e complacente ante tudo e também normalmente humana e terna, agradável para os ouvintes, cuja maior virtude consiste em que tudo pareça fluir do modo de ser das coisas e dos homens, em que a atitude moral do orador resplandeça em seu discurso, dando a se conhecer. ${ }^{5}$

5 “ $\tilde{\eta} \theta$ os, quod intellegimus, quodque à dicentibus desideramus, id erit, quod ante ommia bonitate commendaditur: non solum mite ac placidum, sed plerumque blandum et humanum, et andientibus amabile atque iucundum, in quo exprimendo summa virtus $æ$ est, ut fluere omnia ex natura rerum hominumque videantur utque mores dicentis ex oratione pelluceant et quodam modo agnoscantur". 
Reforçando essas afirmaçóes, Michel Meyer (2007, p. 34) argumenta, a propósito do éthos: "É a imagem de si, o caráter, a personalidade, os traços de comportamento, a escolha de vida e dos fins. Nele está a identificação do orador, do porquê e o papel do orador." Da mesma forma, Reboul (2004, p. 247) realça que é o caráter que o orador deve parecer ter, mostrando-se "[...] sensato, sincero e simpático." Além disso, enfatiza-se o caráter do auditório, a que o orador deve se adaptar. Já para Beristáin (1995, p. 202), “[...] éthos é um estado afetivo que se manifesta com certo grau de satisfação estética. É, de igual maneira, a emoção que pretende suscitar o orador ao público.”

Por último, é pertinente ressaltar que a música traz em seu bojo uma transmissão de um éthos argumentativo, análogo à ética do orador, o qual, por sua vez, é sublinhado por Michael Meyer (2007, p. 35, negrito nosso) como “[...] como princípio (e também como argumento) de autoridade. A ética do orador é seu saber específico de homem, e esse humanismo é a moralidade, que constitui fonte de autoridade." Adicionada a isso, a música tem uma estrutura semântica e gramatical, altamente organizada tal qual a oratória, que se serve dos preceitos da arte da eloquência. Em outras palavras, cada item e ideia processada no discurso musical de muitas peças produzidas nos séculos já citados são mecanismos engenhosos objetivados em despertar diversos afetos, mediante a persuasão.

\section{2 РА́thos}

Persuade-se pela disposição dos ouvintes, quando estes são levados a sentir emoção por meio do discurso, pois os juízos que emitimos variam conforme sentimos tristeza ou alegria, amor ou ódio. (ARISTÓTELES, Ret., I, 1356a, 2005, p. 97).

Para Reboul (2004, p. 251), é por intermédio da ação do orador sobre as paixôes, desejos e emoções do auditório que a persuasão pode ser auferida com maior eficiência. Conforme Meyer (2007, p. 36), “[...] o páthos é a fonte das questōes e essas respondem a interesses múltiplos, dos quais dão prova as paixôes, as emoçóes ou simplesmente as opiniôes." Nele estáo o prazer e o desprazer, o amor, o ódio, desespero, desejo, a dor, entre outros aspectos.

Beristáin (1995, p. 202) assinala que "[...] o páthos é um estado afetivo mais intenso, é uma comoção que atrai o espectador." Consequentemente, 
essa atração se dá tanto para o público da tragédia, ao leitor de epopeia, quanto àqueles que escutam a peroração do orador.

\subsection{Lógos}

Lógos, num primeiro momento, significava a palavra escrita ou o Verbo. ${ }^{6}$ Entretanto, a partir de alguns filósofos gregos, como Heráclito (535 a.C. 475 a.C.), o termo ganha outras acepçôes. Em razão disso, segundo Meyer (2007), há no lógos um conceito filosófico traduzido como razão, o qual pode ser também examinado na retórica como racionalização da argumentação. Ou seja, nele se expressam as perguntas e as respostas, preservando-se sua diferença. Nada obstante, Aristóteles (Ret., I, 1356a, 2005, p. 97) destaca que "[...] o lógos configura-se como argumento lógico do orador, relacionado à retórica e à dialética." 7

Por sua vez, Heidegger (2005) salienta que, em Platão e Aristóteles, o conceito de lógos é polissêmico, isto é, tem vários significados e multiplicidade de sentidos, no entanto, essa gama de possibilidades só terá importância, caso se compreenda o que é a significação básica de um conteúdo, assim como, por exemplo, determinar o que é um discurso:

Em Platão e Aristóteles, o conceito de $\lambda$ ó $\gamma$ os é polissêmico e, de tal modo, que os vários significados tendem a se dispersar, sem a orientaçáo positiva de um sentido básico. Mas, de fato, isso é somente uma aparência que se há de manter enquanto não se puder aprender devidamente o conteúdo primordial de sua significaçáo básica. Quando dizemos que o significado básico de $\lambda$ óyos é discurso, essa tradução literal só terá valor completo quando se determinar o que é um discurso. (HEIDEGGER, 2005, p. 62).

\footnotetext{
${ }^{6}$ Ele também pode ser interpretado como narraçấo, aparecendo como similar de $\mu \tilde{0} \theta$ os (mýthos, mito) em Hesíodo (ca. século XVIII a.C.). Assevera Rodolfo Lopes (2014, p. 40): "Em Hesíodo, (1) a flutuação terminológica mantém-se, (2) o termo mýthos permanece sem receber uma conotação negativa, mas (3) o termo lógos começa a aproximar-se mais do campo semântico do dizer." Por outro lado, o significado Verbo foi adequado por autores cristãos. Escreve Abbagnano (2007, p. 630-631): "No cristianismo, o prólogo do Evangelho de São João, ao lado das funçôes que Fílon de Alexandria (10 a.C.-50 d. C.) já atribuía ao lógos, (pois assim como Deus é o modelo dessa sua imagem ou sombra, o lógos seria o modelo das outras coisas) acrescenta a determinação propriamente cristã: $\mathrm{O}$ Lógos (Verbo, Cristo) fez-se carne e viveu entre nós (Joâo 1:14).”
}

${ }^{7}$ Essa citação também pode ser localizada em Murphy (1989, p. 39-40). 
Adiante, Heidegger (2002, p. 62-63) sublinha que, como discurso, o lógos revela aquilo de que trata o discurso, ou seja, deixa-se apresentar naquilo de que discorre ou fala, tornando-se exequível aos outros:

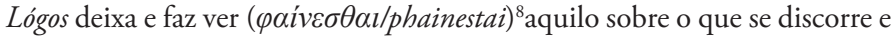
o faz para quem discorre [...] e para todos aqueles que discursam uns com os outros [...]. O discurso autêntico é aquele que retira o que diz respeito sobre que discorre de tal maneira que, em seu discurso, a comunicação discursiva revele e, assim torne acessível aos outros aquilo sobre que discorre. Esta é a estrutura, por exemplo, do lógos. Pois, nem todo discurso possui este modo próprio de revelaçáo no sentido de deixar e fazer ver demonstrando.

Em suma, essa capacidade de quem enuncia o discurso é de desvelar algo do enunciado, o que gera a ação, a performance na retórica, ou seja, a habilidade em convencer, comover.

\section{As FASES RETÓRICAS E SUAS PARTES}

De acordo com Reboul (2004, p. 43), por meio de Aristóteles, a retórica foi "[...] reabilitada e integrada numa visão sistemática do mundo, onde a mesma ocupa seu lugar." Todavia, Aristóteles transformou a retórica em um sistema que, posteriormente, "[...] seus sucessores trataram de desenvolver, todavia, mantendo suas características principais.”

\subsection{INVENTIO 9}

Conforme Reboul (2004, p. 43), “[...] é o encontrar do orador de todos os argumentos e meios de persuasão relacionados ao tema de seu discurso.”

${ }^{8} \mathrm{O}$ termo Fenomenologia, em grego, tem sido usado pelos gregos do modo em que o texto está escrito. Contudo, segundo Abbagnano (2007, p. 437-438), seria “[...] a descriçâo daquilo que aparece ou ciência que tem como objetivo, ou projeto, essa descrição. É provável que esse termo tenha sido cunhado pela escola de Wolff. J. H. Lambert (1728-1777) utiliza-o como título da 4. ${ }^{\text {a }}$ parte do seu Novo Organon (1764)". Igualmente, Japiassú e Marcondes (2001, p. 101-102) destacam que Lambert designou "o estudo puramente descritivo do fenômeno tal qual esse se apresenta à nossa experiência."

9 Não confundir Inventio, que é a capacidade humana, do lógos do homo sapiens, em produzir (conceber, elaborar, realizar em sua escritura) obras de arte, ou seja, que tem a ver com a poíesis do lógos humano, algo de dimensão evidentemente menor e historicamente irrelevante, se pensarmos no tempo no qual as ciências consideram que existe o universo conhecido, com a creatio, que é a poíesis da phýsis, tudo aquilo criado e que existe e se transforma na natureza. 
Nessa fase, acontece a descoberta ou invenção das ideias e argumentos que sustentaráo o discurso e sua tese. Em outras palavras, como frisado por Pedro Persone (1996, p. 28), "[...] o orador tem como tarefa efetuar um argumento adequado para dar sustentação a um tema ou ideia a ser exposta."

$\mathrm{Na}$ Retórica a Herênio (autor anônimo, atribuída, por alguns estudiosos, a Cícero) (I, \$2, 2005, p. 55), lê-se: "A invenção consiste em encontrar argumentos verdadeiros ou verossímeis próprios para tornar a causa convincente." Semelhantemente, Cícero, no De Inventione (I, 1960, p. VII), expóe: "A invenção consiste em imaginar as coisas verdadeiras ou verossímeis, de maneira a fazer admitir a nossa causa."

No entanto, segundo Barthes (1982 [1970]), essa condição remete menos a uma invenção de argumentos do que a um descobrimento, pois se trata mais de uma noção extrativa do que criativa, o que corrobora a designaçáo de um lugar (tópica) de onde se podem extrair as argumentaçôes. Náo significa que tal descobrimento deixasse de lado a criação, mas, a partir dos materiais já existentes, o orador poderia demonstrar sua habilidade em articulá-los.

De igual forma, Sérgio Assumpção (2007) enfatiza que a Inventio é um passo inicial, em que o tópico sobre o qual se vai discorrer, isto é, compor, será fundamento sobre o qual se construirão a representação e a evocação do afeto correspondente. Segundo Bartel (1997, p. 66), “[...] na Inventio, é onde são determinados os sujeitos e, da mesma maneira, nessa etapa as informações são coletadas.”

$\mathrm{Na}$ Inventio, também se encontra o lugar-comum (Locus Topoi/Topici), o qual, segundo Reboul (2004, p. 51), é constituído por “[...] argumentos cautelosamente buscados pelo orador.” Barthes (1982 [1970]) realça que essa parte da Inventio é encarregada de proporcionar conteúdos mais claros e compreensivos dos afetos ao raciocínio humano, tendo como instrumento essencial a tópica.

Em suma, tudo isso vai ao encontro de uma definição de Aristóteles (s/d, p. 33), quando afirma que "[...] um dos papéis da retórica é de ver teoricamente o que, em cada caso, pode ser capaz de gerar a persuasão.” Isto é, arte de descobrir o que é mais adequado à persuasão. 


\subsection{DISPOSITIO}

Distribuiçáo ou arranjo das ideias e argumentos localizados na Inventio, de modo apropriado e eficaz. Para que essa disposição seja orientada e organizada, acontece uma subdivisão tradicional da Dispositio em seções. Essa subdivisão passou por pequenas variaçóes, desde a Antiguidade, entretanto, sua base foi padronizada em seis partes, focalizadas a seguir.

\subsubsection{EXORDIUM}

Para Aristóteles (Ret. III, 1424b, 2005, p. 279), “[...] o proêmio é o início do discurso, que corresponde ao prólogo, na música seria como um prelúdio tocado por um aulo. Todos eles são inícios e servem de preparaçóes do caminho para o que se segue."

Cícero (De. Inv., I, \$20, 1960, p. 40-42, tradução nossa) define-o desta maneira:

O prólogo (exórdio) é um trecho onde a mente do ouvinte é transportada para uma posição apropriada no restante do discurso, fazendo com que o mesmo possa ficar bem atento e receptivo. [...] O exórdio é dividido em introdução e insinuação (persuasão). Uma introdução é algo que de uma forma direta e com uma linguagem simples faz com que o ouvinte fique receptivo e atento. A insinuação é aquilo que por intermédio da simulaçáo e de um processo indireto, se armazena discretamente na mente do ouvinte. ${ }^{10}$

Em Retórica a Herênio (I, \$4, 2005, p. 56), é definida como “[...] o começo do discurso, pelo meio do qual se dispóe o ânimo (espírito) do ouvinte a ouvir." Quintiliano (Inst. Or. IV, I, 1720, p. 298), por sua vez, ressalta que o "Exordium latino equivale ao Prologo dos gregos, constituindo-se na introdução do tema."

\footnotetext{
10 "Exordium est oratio animum auditoris idonee comparans ad reliquam dictionem: quod eveniet, si eum benivolum, attentum, docilem confecerit. [...] Igitur exordium in duas partes dividitur, in principium et insinuationem. Principium est oratio perspicue et protinus perficiens auditorem benivolum aut docilem aut attentum. Insinuatio est oratio quadam dissimulatione et circumitione obscure subiens auditoris animum."
} 


\subsubsection{NARRATIO}

Olivier Reboul (2004, p. 56) disserta que "[...] a narração é a exposição de fatos que dizem respeito à causa, exposição aparentemente objetiva." Aristóteles (Ret. III, 1417a/b, 2005, p. 279, negrito nosso) afirmava que, a partir dessa parte,

[a] narração nos discursos epidícticos não é contínua, mas sim articulada em secçôes, pois é forçoso percorrer os fatos de que o conteúdo do discurso trata. [...] A partir de certos fatos, um indivíduo pode ser apresentado como valoroso, noutras como sábio ou justo. Quanto a fatos bem conhecidos, é necessário apenas recordá-los. [...] o melhor não é a rapidez ou a concisão, mas sim a justa medida. Isto significa falar tanto quanto aquilo de que o assunto necessita para ficar claro. Narra tudo quanto chama a atenção para o teu próprio valor. [...] É conveniente que a narração incida sobre a componente ética, além disso, fala de forma a suscitar emoçóes narrando tanto as consequências que os ouvintes conhecem como os aspectos singulares.

Cícero (De. Inv., I, \$27, 1960 p. 47) explicita que, “[...] na Narratio, acontece a narração do enunciado dos fatos." ${ }^{11}$ Em outra definição, é observável que é nela que as coisas que ocorreram ou poderiam ter ocorrido são expostas (cf. Retórica a Herênio, I, \$4, 2005, p. 56). Já Quintiliano (Inst. Or. IV, II, 1720, p. 318-320) comenta que ela "[...] é uma exposição persuasiva de uma ocorrência verdadeira ou verossímil, a mesma tem que ser exposta na medida certa."

\subsubsection{PROPOSITIO}

Também conhecida como Divisio, de acordo com Retórica a Herênio (I, \$4, 2005, p. 56), “[...] é o meio pelo qual se explícita o que se concorda ou o que está em controvérsia, do mesmo modo o que irá se pronunciar." Aristóteles (2005) trabalha com a Propositio, de forma a suscitar, no momento certo, os afetos no público. Porém, o ilustre mestre da retórica frisa que o orador deve saber produzir esse silogismo retórico que se constitui a estrutura da argumentação retórica, conhecido como entimema, na medida e na hora certa, a fim de não quebrar a emoção de quem está ouvindo:

11 "Narratio est rerum gestarum aut ut gestarum expositio". Citação igualmente localizada em Murphy (1989, p. 139). 
Exemplificação é o que é mais apropriado ao discurso deliberativo, entimemas ao discurso judiciário. Efetivamente, um concerne ao futuro, de forma que é forçoso narrar exemplos de acontecimentos passados; o outro, por seu lado, relaciona-se com fatos que são ou não são, onde é mais necessária a demonstração, pois os fatos do passado implicam um tipo de necessidade. É forçoso, porém, expor os entimemas não de forma contínua, mas intercalados. Se assim não for, prejudicam-se uns aos outros, pois há também um limite na quantidade. Por outro lado, não procures entimemas sobre tudo. De outro modo, farás o que alguns filósofos fazem, que formulam silogismos cujas conclusóes são mais conhecidas e mais plausíveis que as premissas das quais as tiram. E também sempre que suscitares uma emoçáo, não formules um entimema, pois o entimema ou quebrará a emoção, ou será dito em vão; é que movimentos simultâneos chocam uns com os outros, e/ou se anulam, ou se tornam fracos. (ARISTÓTELES, Ret. III, 1418a, 2005, p. 290-291).

\subsubsection{CONFUtaTio}

Segundo Michel Meyer (2007, p. 47), “[...] nessa parte, é onde se deduz os tópicos básicos da conclusão adversa.” Aristóteles (Ret. III, 1416a, 2005, p. 283) declara que tal adversidade pode ser entendida como "[...] o emprego dos mesmos recursos ou elementos pela acusação, de maneira sutil, com o propósito de refutar a suspeita capciosa." Em contrapartida, em Retórica a Herênio (I, \$4, 2005, p. 56), o autor afirma que “[...] a refutação é nada menos que a desconstrução dos argumentos contrários.” De igual maneira, Cícero (De Or. I, XXXI, $\$ 143,1967$, p. 98) observa que, na Refutatio, os argumentos são direcionados contra os adversários em uma audiência. Para isso, utilizamse elementos a favor do orador, com o propósito de debilitar e enfraquecer o oponente: "[...] post que contra dicerentur refellenda, extrema autem oratione a que pro nobis essent amplificanda et augenda, quaque essent pro aduersariis infirmanda atque frangenda. ${ }^{12}$

\subsubsection{CONFIRMATIO}

Confirmação, comprovação ou ainda argumentação contêm as provas e razóes para convencer. Conforme Beristáin (1995, p. 157), “[...] alguns tratadistas consideram que forma parte dela a refutação. Entretanto, outros a veem como independente, sendo a refutação sua antecipação.” Analogamente,

${ }^{12}$ De igual modo, essa traduçấo pode ser localizada em Scatolin (2016, p. 274-275). 
segundo Reboul (2004, p. 56), "[...] a Confirmatio era empregada por alguns autores e oradores, juntamente ou logo após a Narratio."

Por exemplo, para Cícero (1989, p. 148), “[...] a confirmação é a parte da narração que, mediante a ordenação dos argumentos, dá força e autoridade. Ela permite, portanto, estabelecer a matéria-prima da qual se extraem os argumentos." Em Retórica a Herênio, a confirmação é “[...] a apresentação dos argumentos com asseveração.” (I, \$4, 2005, p. 56). Já Quintiliano (Inst. Or., IV, II, 1720, p. 353) exprime que "[...] a confirmação segue a enunciação", e ela é a confirmação da ordem narrativa. O mesmo autor afirma que "[...] tanto a narração como a confirmação devem ser cumpridas pelo orador, todavia, nada o obriga a realizá-las sucessivamente. Em outras palavras, pouco importa a ordem, o importante é que o orador atinja seus objetivos." (REBOUL, 2004, p. 58).

\subsubsection{Peroratio}

De acordo com Beristáin (1995, p. 158), “[...] peroração é a parte do epílogo, onde se encerra o discurso", isto é, a conclusão do discurso feita com maestria, segundo Meyer (2007, p. 47).

Aristóteles (2005, p. 296) detalha que a conclusão do discurso é formada por quatro elementos essenciais para a sustentação do orador, o qual tem por proposta mover as emoçóes (afetos) dos ouvintes:

O epílogo é composto por quatro elementos: tornar o ouvinte favorável para a causa do orador e desfavorável para a do adversário; amplificar ou minimizar; dispor o ouvinte para um comportamento emocional; recapitular. Após ter-se mostrado que se diz a verdade e o adversário, falsidade, faça-se um elogio ou uma censura, e finalmente sublinhe-se de novo o assunto. [...] Depois, estando em evidência tanto as qualidades como as dimensóes dos fatos, convém provocar no ouvinte, comportamentos emocionais.

Por outro lado, Cícero (1989, p. 149) enfatiza que a peroração completa o discurso e tem três partes: "[...] o resumo do que foi discutido em todo o discurso, a provocação e animosidade com o adversário e, finalmente, a provocação da simpatia para com o público.” Na Retórica a Herênio, examinase que "[...] a peroratio é a conclusão do discurso, ou seja, onde se tem o término do mesmo, de acordo com as regras de arte." (2005, p. 56). 


\subsection{ELOCUTIO}

Conforme Helena Beristáin (1995, p. 168) e Heinrich Lausberg (2004, p. 115-116), a terceira fase retórica, na tradição gregoriana, "[...] corresponde à expressão linguística verba dos pensamentos (res) encontrados na Inventio e combinados na Dispositio, pelo orador." Ela apresenta uma multiplicidade, dirigida por possibilidades linguísticas de expressão, as quais são sistematizadas como genera elocutionis (cf. LAUSBERG, 2004, p. 116).

Semelhantemente, a elocução do discurso é a base de sua organização; descoberta da expressão para cada ideia, incluindo o estudo das figuras ou tropos $^{13}$, em que as regras estilísticas são ensinadas. Também podem ser acrescidas ornamentaçóes e junçôes entre partes e alteraçóes de estilo. Nessa fase do discurso retórico, o orador escolhe e junta as palavras, para depois ordená-las, visando, assim, ao melhor resultado, tanto na compreensão do ouvinte quanto do orador. Segundo Cícero (De Or. I, XIX, $\$ 85,1967$, p. 61), "[...] nessa fase, o orador enuncia seu discurso com maior peculiaridade." Reboul (2004, p. 61) complementa, ressaltando que, no sentido técnico, "[...] se trata da redação do discurso.”

Duas regras são as que orientam essa fase do discurso: a do decoro e a da clareza. A primeira tem por objetivo ajustar um assunto à função do discurso, ou seja, cada assunto e função exigem um estilo diferente; a segunda é uma solicitação para uma adequação do estilo ao auditório.

Outro aspecto relevante refere-se aos gêneros de estilos sobre os quais o orador deveria ter domínio, habilidade, além de saber o momento propício para empregá-los. Cícero (De Or., I, XVII-XXI, \$ 74-97, 1967, p. 55-70, passim, negritos nossos) os dispóe, como indicado a seguir.

Estilo baixo: (estilo tênuel humilis). Esse só quer ensinar (docere) e provar (probare). Suas virtudes são, portanto, a pureza e a perspicácia. Também, trabalha com a matéria comum, diária e pequena.

Estilo médio (estilo mediocris). Gracioso, pelo fato de querer deleitar (delectare). O grau de afeto correspondente é o éthos, igualmente é o mais indicado para persuadir o ouvinte.

\footnotetext{
${ }^{13}$ Tropo [do gr. trópos, "desvio", pelo lat. tropu]. É o emprego da palavra ou expressão em sentido figurado, na música medieval. Era usado na ampliaçâo de um canto litúrgico de formação melismática, mediante acréscimos ou substituiçôes. A primeira manifestação dramática aconteceu na Idade Média e se constituía de pequeno recitativo ou diálogo inserido na liturgia da missa, donde se originaram os dramas litúrgicos (v. drama litúrgico).
} 
Estilo alto (estilo sublimelgrave). É patético, porque há a intenção de comover e mover (comovere/movere). Nesse, o orador deve suscitar no ouvinte os afetos de alegria, tristeza, ira, ódio, inveja, compaixão, esperança, desesperança, medo, entre outros.

Em síntese, como disserta Dietrich Bartel (1997, p. 66), “[...] é na Elocutio que as diversas ideias e pensamentos são traduzidos em palavras e sentenças, somando, assim, todos os dispositivos necessários para uma fundamentação e argumentação com maior ênfase."

\subsection{MEMORIA}

Sáo mecanismos e processos para memorizar o discurso e, por extensão, o modo operativo de cada uma das fases retóricas. Esses instrumentos e processos de memorização, atribuídos ao orador, permitem que ele possa realizar seu discurso com maior desenvoltura e confiança. Tendo o orador discursado e corretamente memorizado as ideias e os argumentos, e da mesma forma demonstrando domínio em sua execução, ia ganhando, com o tempo, maior credibilidade e autoridade.

Na mesma linha de pensamento, Olivier Reboul (2004) explica que a memória depende do estado físico do orador, por exemplo, se ele está com boa saúde, se dormiu bem. Posteriormente, um discurso só será fácil de memorizar mediante sua estrutura e pelo encadeamento lógico de suas partes. Uma vez dominado, o discurso pode ser proferido com solidez e segurança, assim conquistando a atenção do auditório.

Portanto, como destaca Beristáin (1995), a Memoria corresponde à aprendizagem das ideias fundamentais do discurso ou de sua elaboração e formulação elocutiva, mediante a ajuda de uma técnica ordenadora, habitual entre os oradores.

\subsection{PRonuntiatio}

A quinta e última fase da retórica é também conhecida na tradição grega como Actio ou Hipocrisis. Trata-se da concretização do discurso ante o público, quando são revisados os princípios fonéticos e gestuais que se devem 
observar durante a execução pública. Na Antiguidade, por exemplo, o orador era posto em cena, ao recitar seu discurso como um ator.

Com a dicção adequada e os gestos pertinentes para realizá-la, poderia ter êxito no efeito proposto. Da mesma maneira, conforme Helena Beristáin (1995, p. 401), “[...] consiste no emprego da palavra e na pronúncia das expressóes. Nele sáo considerados tudo o que se relacionava com a voz e com o corpo."

Quintiliano (Inst. Or., X, I, $\$ 2,1885$, p. 2, tradução nossa) afirma:

$\mathrm{Na}$ verdade, elas [a escrita, a leitura e a fala] formam de tal modo um todo conexo e indiscriminável, as quais estão intimamente relacionadas e são inseparáveis: se uma delas falta, empregaremos todos os nossos esforços em vão. Por isso, a oratória (eloquência) só será eficaz se apenas retirar suas forças do exercício escrito. Sem o exemplo dado pela leitura, o objetivo do trabalho escrito (na falta de um guia) será vago e instável. Portanto, aquele que náo sabe falar adequadamente e sem sensibilidade aguçada (eloquência), isto é, com nenhum aprimoramento na oratória, será como um guarda de um tesouro fechado. ${ }^{14}$

Há de se ressaltar, ainda, que os teóricos da retórica dedicam também grandes espaços ao estudo da origem e funcionamento dos afetos. Despertar, mover e controlar as paixóes nos ouvintes é tarefa fundamental no trabalho persuasivo do orador.

\section{A RELAÇÁo ENTRE RETÓRICA, FILOSOFIA E HERMENÊUTICA}

Segundo Soares (2012), entre o florescimento do Medievo até a Renascença, a retórica foi a base da articulação da Escolástica ${ }^{15}$ e, por ela,

\footnotetext{
14 "Verum ita sunt inter se conexa et indiscreta omnia, ut, si quid ex his defuerit, frustra sit in ceteris laboratum. Nam neque solida atque robusta fuerit umquam eloquentia, nisi multo stilo vires acceperit, et citra lectionis exemplum labor ille carens rectore fluitabit, et qui sciet, que quoque sint modo dicenda, nisi tamquam in procinctu paratamque ad omnes casus habuerit eloquentiam, velut clausis thesauris incubabit." Essa citação e tradução de Quintiliano também podem ser localizadas em Rezende (2009, p. 186) e Lucas (2010, p. 5).

${ }^{15}$ Conjunto de doutrinas filosóficas e teológicas desenvolvidas em escolas eclesiásticas e universidades da Europa, entre os séculos IX e XVI. Caracteriza-se pela tentativa de conciliar a fé cristá com a razão pelos estudiosos cristãos. Agostinho de Hipona, por exemplo, é influenciado pelos princípios da filosofia clássica grega, em especial os ensinamentos de Platáo e Aristóteles. Desenvolve-se a partir da filosofia patrística, a qual faz a primeira aproximação entre o cristianismo e uma forma racional de organizar a fé e seus princípios, baseada no platonismo.
} 
tanto a Filosofia, a Hermenêutica e a Música continuavam associadas à religião, uma vez que são as questóes teológicas que suscitam a discussão filosófica. Esse debate é referido por Danilo Marcondes (2001) como um momento de compartilhamento e aceitação de certos princípios doutrinários comuns, análogos a assuntos concernentes aos dogmas do cristianismo. O desenvolvimento do pensamento escolástico deu-se principalmente pelo estabelecimento do ensinamento das sete artes liberais. ${ }^{16}$

Ademais, de acordo com Miguel Baptista Pereira (1994), dois fenômenos interligados assinalam o pensamento contemporâneo: o regresso da Retórica e o que já se denominou a idade hermenêutica da razão. Assim, as teorias da argumentação e da verdade como consenso são tipos de exposição modelar à influência da Retórica, como, aliás, a noção de texto, táo fecunda para as concepçôes literárias e filosóficas do Ocidente, traz a marca de uma ascendência retórica, complementada pelo conceito de narração e de intriga da Poética de Aristóteles.

Somado a isso, como acentua Pereira (1994, p. 6-7), o fim da retórica como disciplina docens não coincide com o desaparecimento da práxis retórica (rhetorica utens, oratoria, eloquentia), nem de modo algum com a extinção da sua existência residual em teorias de composição literária, em regras de comportamento, em expressóes do discurso pragmático, nem com o término de sua eficácia histórica na tipologia variada da história das ideias e da cultura. Logo, a teoria retórica do texto, bem como sua influência histórica, a que o Ocidente se expôs, merecem particular atenção, dadas as suas estritas relações com a Filosofia, Hermenêutica e Música, pois,

[...] a análise hodierna do texto retórico franqueia as portas não só à investigaçáo dos seus modos de sobrevivência histórica nas construções linguísticas e em textos extralinguísticos, como, v.g., a arte oratória de J. S. Bach, a pintura de quattrocento ou o sonho como elocutio em Freud, mas, também, ao estudo do poder do texto, da sua aptidão para docere, delectare et movere, da sua capacidade de socializaçáo e de construçáo de consensos políticos.

Efetivamente, como afirma Pereira (1994), desde a metade do século $\mathrm{XX}$, avolumaram-se os estudos sobre a influência da retórica no campo das ideias estéticas, religiosas, literárias, exegéticas, jurídicas, antropológicas, sociais

16 Constituída pelo Trivium (Gramática, Retórica e Dialética) e pelo Quadrivium (Aritmética, Geometria, Música e Astronomia). 
e políticas, pelo papel da retórica nos pensamentos alógicos pré-românticos, tal como no pensamento augustiniano do discurso cristão, na estética de Alexander Gottlieb Baumgarten (1714-1762), no papel desempenhado por Giovan Battista Vico (1668-1744), no aclarar do pensamento moderno, na eloquência do pietismo, na hermenêutica, na retórica absoluta de Wilhelm Friedrich Von Schlegel (1772-1829), na teoria dos tropos de Friedrich Wilhelm Nietzsche (1844-1900), na educação, na teoria da comunicação, no domínio da antropologia, na teoria da argumentação jurídica e política, na teoria da razão prática e nas relaçôes com o pensamento selvagem.

Dessa maneira, houve uma comparação entre a retórica clássica e a unidade das partes do discurso, concebida como Dispositio (ordenação do discurso), ou seja, uma relação entre a cabeça com os membros e partes do corpo do enunciado ou texto. Miguel Pereira (1994) salienta que, através de um exame minucioso de Matthias Flacius Illyricus (1520-1575), no século XVI, verificou-se que essa analogia está longe de ser uma série de palavras e frases, ao contrário, ela é baseada numa harmonia das suas partes, como um ser vivo, segundo o testemunho de Platáo (428/427-348/347 a.C.), no Fedro (370 a.C.), e o de Aristóteles, na Poética (335-323 a.C.), quando toma como parâmetro para a estrutura da tragédia a unidade de um corpo vivo, justificando uma anatomia do texto. Em suma, essa ideia de harmonização no discurso pode ser reforçada pela metáfora de livro, enfatizada por Pereira (1994, p. 9), “[...] como expressóes Livro da Vida (Êxodo 32: 32), Livro com Sete Selos (Apocalipse cap. 5 e 6) e Livro da Natureza (Alano de Lille)", os quais, conforme ele (1994, p. 9), "[...] transcendem a esfera prédica e penetram no pensamento filosófico e teológico da Idade Média com traços bem visíveis na Filosofia Moderna e com claras incidências em pensadores do Romantismo.”

Já na Idade Moderna, uma nova hermenêutica da Bíblia é empregada, por razão da inclusão das ciências filológicas clássicas na exegese antiga, o que possibilitou uma transferência dos textos essenciais numa situação cultural moderna. Nesse aspecto, Miguel Pereira (1994, p. 10., negritos nossos) salienta:

Na Modernidade, nasceu uma nova Hermenêutica da Bíblia em virtude da incorporação das ciências filológicas clássicas na exegese antiga, o que permitiu transferir para uma situaçáo cultural moderna o essencial do sentido, que os textos assumiram numa situaçáo cultural, que deixou de ser a nossa. Perfila-se aqui uma problemática, que não é característica dos textos bíblicos ou religiosos, isto é, a luta contra a má compreensão oriunda da distância cultural, pois interpretar é, doravante, traduzir a significação 
ou sentido de um escrito de um contexto cultural para outro segundo uma regra de equivalência de sentido. Outro lugar de origem da Hermenêutica foi a Filologia dos textos clássicos, que, desde a Renascença e, sobretudo, desde o século XVIII, constituiu um campo autônomo de interpretação relativamente ao da fé, em que se tratava, outrossim, da restituição de sentido de textos antigos ou da sua transferência e tradução apesar da distância cultural e temporal. É a diferença e, simultaneamente, a referência do texto ao contexto, que fundam a capacidade de o texto se descontextualizar, isto é, de se libertar do seu contexto inicial para se recontextualizar numa situação cultural nova, preservando a sua identidade semântica, como acontece paradigmaticamente na tradução.

Destarte, segundo Pereira (1994, p. 52-53), com a redescoberta da Antiguidade Clássica, combinada com a invenção da imprensa, com o impulso dado à difusão do livro, da leitura pela Reforma e a entrada em penumbra da oralidade,

[...] a compreensão teológica da Bíblia e a análise filológica do texto clássico desenvolvem uma ciência interpretativa da leitura, que rivaliza com o estilo de ciência forjado na interpretação matemática do livro da Natureza. Antes mesmo que Johann Conrad Danhauer (1603-1666) usasse pela primeira vez o nome Hermenêutica em 1626, a prioridade e o relevo da escrita fizeram insensivelmente deslocar para a Hermenêutica a tarefa da Retórica, que a era do discurso oral consagrara. Nesta transferência, o sentido aleteológico, que justificava a Retórica, anima agora a interpretaçáo de textos paradigmáticos, cuja verdade é o ideal da imitatio. Filipe Melanchton (1497-1560) estimou a importância da Retórica, porque por meio dela os jovens exercitavam a ars berre legendi, isto é, a capacidade de compreender e de julgar os discursos, as disputas mais longas e sobretudo os livros e os textos. Para a compreensão do texto, a tônica dominante, segundo Melanchton, é a intenção fundamental, o ponto de vista central ou o scopus do discurso.

Enfim, conforme Hans-Georg Gadamer (1900-2002), o grande legado da retórica continua a influenciar pontos decisivos em relação à nova interpretação dos textos.

Assim como a verdadeira retórica é inseparável, para o discípulo de Platão, do conhecimento das coisas, sob pena de sucumbir ao nada puro, também é para a interpretação dos textos que se postula o óbvio de que contêm a verdade sobre as coisas. (1992, p. 272). 
Após essas afirmações, é pertinente buscar compreender a natureza estrutural da retórica musical, por meio da necessidade de um exercício hermenêutico e filosófico de interpretar, em um contexto sociocultural, a adequação de uma ação balizada em conhecimentos éticos. Em outras palavras, na sabedoria prática, conhecida como phrónesis aristotélica, interagindo ações pragmáticas que visam a procurar um estado de sublimidade, tendo como pretensão e ponto comum: a virtude, o que, segundo Aristóteles (EN. VI, 5, 1140b, 1-5, p. 144), se mostra como "[...] uma capacidade verdadeira e raciocinada de agir com respeito às coisas boas ou más para com o ser humano.”

\section{Retórica E MÚSICA: OS TRATADOS}

Na história da civilização ocidental, a música também se desenvolveu por considerável tempo, no âmbito vocal, ligada às palavras. As relaçôes entre retórica e música foram, assim, desde a Antiguidade, bastante estreitas. No Barroco, essa relação chegou a um ponto sofisticado de aplicação. Aqui as influências dos princípios básicos da retórica afetaram profundamente os elementos mais íntimos da linguagem musical. Entretanto, as inter-relações entre música e as artes (artes dicendi), gramática, retórica e dialética são, ao mesmo tempo, óbvias e confusas para que se possa compreendê-las. Os compositores eram influenciados por doutrinas retóricas que governavam a adequação dos textos e da música e, também, depois do crescimento da música instrumental independente, os princípios retóricos continuaram a ser empregados por algum tempo, não só na música vocal, mas, de igual modo, na música instrumental.

A partir do princípio do século XIX, os músicos e estudiosos "modernos" não estavam tão interessados nas disciplinas retóricas. De acordo com Buelow (2001, p. 260), “[...] somente no início do século XX os pesquisadores e historiadores da música redescobriram a relevância da retórica como a base de conceitos teóricos e estéticos da música anterior." ${ }^{17}$

É pertinente ainda reiterar, em parte, que, na área musical, todos os conceitos musicais relacionados à retórica procedem de extensa literatura sobre oratória e retórica dos antigos escritores gregos e romanos, especialmente Aristóteles, Cícero e Quintiliano. O redescobrimento, em 1416, do Institutio Oratoria proporcionou uma das fontes primárias sobre a qual se baseou

${ }^{17} \mathrm{Na}$ metade da década de 1960, a retórica passa a ser considerada como nova ferramenta de análise musical. 
a nascente união entre retórica e música, no século XVI, tendo como contribuição uma teorização sistematizada mediante tratados de retórica e poética musical, dos quais podem ser destacados:

- Musica (1537), de Nicolaus Listenius (1510-?).

- Musica Poetica (1548) e Compendiolum Musica (1548), de Heinrich Faber (1500-1552).

- L'antica musica ridotta alla moderna prattica (1555), de Nicola Vicentino (1511-1575-6).

- Le Istitutioni Harmoniche (1558), de Gioseffo Zarlino (15171590).

- Praecepta Musica Poetica (1563), de Gallus Dressler (1533-1589).

- Hypomnematum musica poetica (1599), Musica autoschédiastikè (1601) e Musica Poetica (1606), de Joachim Burmeister (15641629).

- Sinopse Musice Nova (1612), de Johannes Lipius (1585-1612).

- Musices Poetica (1613), de Johannes Nucius (1556-1620).

- Compendium Musica (1618), de René Descartes (1596-1650).

- Opusculum Bipartitum de Primordiis Musicis (1624), de Joachim Thuringus (nascido em finais do século XVI).

- Traité de l'Harmonie Universelle (1636-1637), de Marin Mersenne (1588-1648).

- Musica Poetica (1643) e Musica Moderna Prattica (1653), de Johann Andreas Herbst (1588-1666).

- Musurgia Universalis (1650), de Athanasius Kircher (1601-1680).

- Tractatus Augmentatu Compositionis (1657), de Christoph Bernhard (1628-1692).

- Musikalisches Frühlings, Sommer, Herbst, und Winter-Gespräche (1695-1701), de Johann Georg Ahle (1651-1706).

- Clavis ad thesaurum magne musica artis (1701), de Tomas Baltazar Janovka (1669-1741). 
- Der Pracepta musicalischen Composition (1708) e Musicalisches Lexicon (1732), de Johann Gottfried Walther (1684-1748).

- Tractatus Musicus Compositorio-Practicus (1745), de Meinrad Spiess (1683- 1761).

- Critische Der Musikus (1745), de Johann Adolf Scheibe (17081776).

- Allgemeine Geschichte der Musik (1788-1801), de Johann Nikolaus Forkel (1749-1818).

- Versch Einer Anleitung zur Composition (1782-1793) e Musikalisches Lexikon (1802), de Heinrich Christoph Koch (1749-1816).

Contemporâneo de todos esses tratadistas, Johann Mattheson (16811764), em seu tratado Der Vollkommene Capellmeister (1739) (O Mestre de Capela Perfeito), elaborou um padrão composicional fundamentado na disciplina retórica, de modo a provocar no discurso musical a mesma eficácia persuasiva da arte da oratória. Respaldado pelos cânones clássicos, estabelece, por meio das Cinco Fases da Retórica, maior relação entre a música e o discurso, evidenciada a seguir.

- Inventio - início do discurso onde são descobertas pelo orador as ideias e os argumentos que sustentarão a sua tese, podendo abranger $\mathrm{o}$ ato de invenção, das ideias musicais, entre outros.

- Dispositio - onde são distribuídas e ordenadas as ideias e argumentos encontrados na Inventio.

- Elocutio - é associada ao estilo. Nela são efetuados os processos de tratamento e desenvolvimento de cada ideia, item e ornamentaçáo, também denominada Decoratio ou Elaboratio por outros autores.

- Memoria - são os mecanismos e processos utilizados para memorizar o discurso e, por extensão, o sistema operacional de cada uma das fases retóricas.

- Pronuntiatio - pronunciamento do discurso. É a última fase do sistema retórico, igualmente conhecida como actio ou ação (atuação). Diz respeito à performance, isto é, à interpretaçáo-execuçáo perante o público. (BUELOW, 2001, p. 261). 
Referente à Dispositio, alguns tratadistas, como Gallus Dressler e posteriormente Joachim Burmeister, estabeleceram uma versão simplificada em três partes (Exordium, Medium e Finis). Todavia, em conformidade aos mestres da retórica e oratória clássica, Johann Mattheson amplia e ordena em seis partes, desta forma:

1. Exordium - "introdução e início de uma melodia, pela qual sua finalidade e intenção devem ser apresentadas, de maneira a preparar e estimular a atençáo do ouvinte. Frequentemente, quando se examina uma obra sem instrumentos, somente com a parte vocal e o baixo, esta introdução acontece na passagem do baixo contínuo que antecede a entrada da voz; se um acompanhamento maior está presente, essa introdução ocorre no ritornello. Pois, nós chamamos a parte que ocorre no início e com instrumentos de ritornello: porque, posteriormente, ela é repetida, e a obra pode facilmente tanto terminar quanto iniciar com ela".

2. Narratio - "é um relato, uma narração, por meio do qual o sentido e o caráter do discurso aqui são sugeridos. Ocorre com a entrada, início da parte vocal ou da parte concertada (instrumental) mais importante, e é relacionada ao Exordium, que o precedeu, por meio de uma hábil conexão"18.

3. Propositio ou Divisio - "é quando o discurso propriamente dito contém, de forma sucinta (resumida), o conteúdo e propósito do discurso musical, e é de duas variedades: simples ou composto. [...] Esse discurso ocorre imediatamente após o primeiro inciso da melodia, nomeadamente quando o baixo toma a frente e apresenta a melodia tão simples e brevemente. Depois, a parte vocal começa sua propositio nem variatam, une-se com o baixo contínuo e realiza o discurso combinado".

4. Confutatio - "é a clarificação das objeçôes (isso é, ideias musicais oponentes ou contrastantes), e pode ser expressa na melodia tanto através da combinação, citação ou refutação de elementos estranhos à música que se precedeu".

5. Confirmatio - "é a corroboração (reforço e reafirmação) artística do discurso, e em melodias, é comumente encontrada em repetições imaginativas e inesperadas; o que náo deve ser entendido como uma reprise normal. Referimo-nos à introdução de certas passagens vocais agradáveis ornamentadas com todos os tipos de boas variações [...]".

\footnotetext{
${ }^{18}$ Mattheson alude à entrada do solo vocal e instrumental da Narratio, nas árias, porém, a narraçáo do discurso, dependendo do texto e contexto, náo necessariamente acontece na voz preponderante, podendo ser realizada em todas as vozes.
} 
6. Peroratio - "é o final ou conclusão de nossa oração musical, que deve produzir uma impressão especialmente enfática, mais do que as outras partes. E isto ocorre não apenas no curso ou progresso da própria melodia, mas especialmente no epílogo, seja ele tocado pelo baixo contínuo ou por um forte acompanhamento; tenha ou não alguém ouvido este ritornello antes”. (MATTHESON, II, 14, \$7-12, 1954 [1739], p. 236). ${ }^{19}$

\section{O EMPREGO RETÓRICO POR ALGUNS COMPOSITORES DO BRASIL COLONIAL}

Como salientado na introdução, o discurso musical, entre o final do século XVI e início do XIX, era constituído por elementos retóricos, associados a uma elaboração, organização e disposição fundamentada a serviço da eloquência e persuasão. Tal fato é destacado por Soares, Novaes e Machado Neto (2012b), sendo observável desde a Antiguidade greco-romana, consubstanciado em sistematização e teorização associadas aos notáveis mestres, pensadores, tratadistas e autores de peças musicais, servindo, desse modo, de embasamento para a concepção estrutural de uma música.

\footnotetext{
19 "Das Exordium ist der Eingang und Anfang einer Melodie, worin zugleich der Zweck und die gantze Absicht derselben angezeiget werden muss, damit die Zuhörer dazu vorbereitet, und zur Aufmercksamkeit ermuntern werden. Mehrentheils, wenn wir einen Satz ohne Instrumente, nur mit der Singstimme und dem Bass betrachten, stehet dieser Eingang in dem Vorspiele des Generalbasses; wenn eine grössere Begleitung daben ist, in dem Ritornell. Denn wir nennen auch dasjenige ein Ritornell, was mit Instrumenten vorher gespielet wird: weil es hernach zur Wiederkehr dienet, und damit sowol geschlossen, als angefangen werden kan. Die Narratio ist gleichsam ein Bericht, eine Erzehlung, wodurch die Meinung und Beschaffenheit des instehenden Vortrages angedeutet wird. Sie findet sich gleich bey dem An = oder Eintritt der Singe= oder vornehmsten Concert=Stimme, und beziehet sich auf das Exordium, welches vorhergegangen ist, mittelst eines geschickten Zusammenhanges. Die Propositio oder der eigentliche Vortrag enthält kürtzlich den Inhalt oder Zweck der Klang-Rede, und ist zweierlei: einfach, oder zusammengesetzet [...] Solcher Vortrag hat seine Stelle gleich nach dem ersten Absatz in der Melodie, wenn nehmlich der Bass gleichsam das Wort führet, und die Sache selbst so kurtz als einfach vorleget. Daraus hebt denn die Sing=Stimme ihre propositionem variatam an, vereiniget sich mit dem Fundament, und erfüllet den zusammengesetzten Vortrag. [...] Die Confutatio ist eine Auflösung der Einwürffe, und mag in der Melodie entweder durch Bindungen, oder auch durch Anführung und Wiederlegung fremdscheinender Fälle ausgedruckt werden [...] Die Confirmatio ist eine künstliche Bekräfftigung des Vortrages, und wird gemeiniglich in den Melodien bey wolersonnenen und über Vermuthen angebrachten Wiederholungen gefunden; worunter aber die gewöhnlichen Reprisen nicht zu verstehen sind. Die mehrmahlige mit allerhand artigen Veränderungen gezierte Einführung gewisser angenehmer Stimm=Fälle ist es, was wir hier meinen [...] Die Peroratio endlich ist der Ausgang oder Beschluss unsrer Klang-Rede, welcher, vor allen andern Stücken eine besonders nachdrückliche Bewegung verursachen muss. Und diese findet sich nicht allein im Lauffe oder Fortgange der Melodie, sondern vornehmlich in dem Nachspiele, es seyim fundament, oder in einer stärckern Begleitung; man habe dieses Ritornell vorher gehöret oder nicht. Die Gewohnheit hat es so eingeführet, dass wir in den Arien fast mit eben denjenigen Gängen und Klängen schliessen, darin wir angefangen haben: weichem nach unser Exordium auch alsdenn die Stelle einer Peroration vertrit." Igualmente, essa tradução e citação podem ser encontradas em Vidal (2002, p. 63) e Lucas (2010, p. 6-7, aula sobre Dispositio).
} 
Do mesmo modo, na música colonial brasileira, os mesmos princípios retóricos foram usados pelos mestres da composição. Por exemplo, Manuel Dias de Oliveira expressa a utilização de semelhantes artifícios, o que pode ser notado, no Moteto dos Passos, em $O$ vos omnes:

Em $O$ vos omnes, de Manuel Dias de Oliveira, encontramos o mesmo tipo de baixo cromático utilizado para retratar uma situaçáo de tristeza desesperada, que aparecera como ostinato no Lamento de Cassandra, da ópera Didone (1641), de Francesco Cavalli (1602-1676). (DOTTORI, 1992, apud RICCIARDI, 2000, p. 28).

No caso da "situação de tristeza desesperada", trata-se de um mecanismo trabalhado por Manuel Dias de Oliveira, a fim de descrever o afeto de angústia, languidez e lamúria, representado entre os compassos 42 e 44, da referida peça, pela figura da Pathopoeia (páthos, que, em grego, significa toda forma de afecção, seja emotiva, seja física, assim como de sentimento humano, paixão, carinho, poeia, apresentação, expressão). Segundo Dietrich Bartel (1997, p. 362), a "Pathopoeia é uma representação viva de um afeto intenso e veemente. Além disso, ela pode ser usada para expressar afeição melancólica ou triste."

Na mesma obra, de acordo com Maurício Dottori (1992, p. 53), "Manuel Dias de Oliveira, através dos mecanismos retóricos, ressalta as frequentes cadências ou as linhas do contraponto adicionadas à ênfase dos afetos". Somado a isso, Soares (2017, p. 281-282) disserta que o compositor mineiro emprega a figura retórica de repetição melódica Anaphora e a de dissonância e deslocamento Synaeresis, nas quais duas notas são colocadas numa sílaba, para destacar o afeto de angústia e tristeza:

Entre os compassos 15 e 20, observa-se a repetição melódica contínua na voz do baixo nas palavras transeat a me (afaste de mim). Dessa maneira, constata-se o uso da Anaphora para destacar o afeto de angústia e langor, expressos por Cristo, descrito em Mateus 26:39, "Pai, se possível, afasta de mim este cálice”.

Soares (2019, p. 11-12) continua:

Igualmente, é verificável a aplicação da Synaeresis, para reforçar esse sentimento, o qual é trabalhado por Dias de Oliveira, seja nos diálogos entre as funções harmônicas da Tônica e Dominante como nas vozes. 
Igualmente, Júlio Cesar Moretzsohn (2008, p. 74-76, negritos nossos) sublinha que Lobo de Mesquita e outros compositores de sua época utilizam, em suas missas, os mesmos contrastes de afetos que são uma das mais relevantes características do Barroco:

"A palavra afeto (affectus, em latim) vem da tradução do termo grego páthos. Sua raiz está no verbo adficere, que significa influenciar, afetar. [...] Os compositores foram influenciados por doutrinas retóricas, que se preocupavam com as relaçóes entre texto e música. Nos séculos XVII e XVIII essa dimensão foi ampliada ao extremo, e um dos principais objetivos da música dessa época era despertar no ouvinte uma grande variedade de sentimentos e ideias, designados como afetos. [...] Um dos principais recursos adotados para se despertar esses afetos fora o uso de figuras retórico-musicais. [...] Esses procedimentos tiveram grande influência sobre as Missas do século XVIII.”

Na mesma linha, Katya Beatriz de Oliveira (2011, p. 37, negrito nosso) observa que José Joaquim Emerico Lobo de Mesquita, em suas missas, "[...] faz uso das figuras retórico-musicais para realçar as dinâmicas, e as mudanças de atmosfera mais adequadas às imagens indicadas no texto ou afeto representado."

Já Robson Bessa Costa (2006, p. 24, negrito nosso) assinala que Lobo de Mesquita "[...] usa as figuras retóricas para enfatizar as complexidades das figuras rítmicas em simultaneidade aos elementos contrastantes." Em conformidade a isso, Soares e Machado Neto (2015, p. 365-366) ressaltam que Lobo de Mesquita utiliza a Abruptio, figura retórica que interrompe um trecho musical mediante pausas, para valorar as funçôes harmônicas, as dinâmicas, além dos motivos e das frases musicais:

\footnotetext{
Na quinta parte da Dispositio, no terceiro tempo do compasso 77, verificase a aplicação desse recurso retórico onde a expressão salutari Dei, nas vozes da soprano, tenor e baixo, são interrompidas de maneira súbita e inesperada. Outro aspecto relevante a ser salientado são as funçóes harmônicas da Dominante da Subdominante relativa, Dominante, Subdominante e Tônica, trabalhadas pelo autor em consonância às dinâmicas piano e forte, valorando, dessa forma, a repetiçáo enfática tanto do motivo, da frase e das palavras.
}

Não obstante, Gomes et al. (1998, p. 17-18, negritos nossos) salientam a relevância da instrução retórica para os compositores obterem exposição satisfatória e consistente: 
Daqui pode concluir o Compositor instruído, não só como Filósofo, a entidade diferente de cada um dos sobreditos empregos; podendo justamente distinguir o Contraponto Harmonia Docente, e a Composiçáo Harmonia Utente, isto é, parte que dá preceitos; e parte que os apresenta em execução; mas também pode observar como Retórico a analogia da Faculdade Harmônica com a Faculdade Retórica; aqui se observa o Contraponto relativo à parte da Invençáo e a Composiçáo relativa à Disposiçáo e à Elocuçáo. Na Dissertaçáo que serve de princípio a esta obra fica após demonstrado quanto é preciosa ao compositor a Instrução Literária.

Em outra passagem de seu tratado de contraponto, Gomes et al. (1998, p. 179-180, negritos nossos) observam que os compositores e os estudantes de composição deveriam verificar, estudar e imitar os preciosos tratados deixados pelos notabilíssimos mestres, além dos preceitos próprios da Faculdade Retórica e Poética:

É verdade que todos os nossos esforços tornariam inúteis, uma vez que nos considerássemos destituídos dos dons da natureza, mas igualmente esses mesmos dons da natureza, ainda que modificados pela Arte, náo poderáo avançar um dilatado terreno sem que sejam acompanhados, ajustados e socorridos pelos ótimos exemplares de insignes Mestres, aos quais nos comunicam em não sei que virtude particular e oculta, que é só a que nos desembaraça na mesma execução dos preceitos da Arte; muitos deles rigorosamente estabelecidos pelos Antigos Mestres que nestes tempos têm elevado ao mais alto ponto de perfeiçáo a Composiçáo da Música, sendo também inegável que estes mesmos Mestres tiveram a precisão de imitar outros famosos Modelos, e polidos também por este Meio os seus felizes talentos, aumentando e ainda polindo, por meio de novas descobertas, aquelas científicas produçóes, nos transmitem e expóem a nossa admiração, autorizados Modelos, que imitemos; e em que igualmente aperfeiçoemos e dilatemos as nossas ideias [...] Na experiência de todos os dias, nós vemos a grande utilidade que resulta da Imitaçáo e que longe de enfraquecer e sufocar; pelo contrário, ela corrobora, aumenta, dilata e faz realçar a mesma natureza. Revela, pois, saber manejar, define um empréstimo de ideias de pensamentos, de sentimentos e passagens dos escolhidos exemplares que nos propomos a imitar ou aproximando-os ou diferenciando-os, ou diminuindo, ou aumentando, os quais preceitos, próprios da Faculdade Retórica e Poética, nos quais supomos o nosso aluno de Composição de Música bem instruído, como preparatórios desta Faculdade que tratamos; por isto deixamos aqui de os explicar. 
Por conseguinte, Cleofe Person de Mattos (1997) realça que José Maurício Nunes Garcia, sempre reconhecido pelos seus mestres como aluno de excelente desempenho intelectual, demonstrou a influência da retórica, disciplina estudada por ele desde sua juventude, tanto na arte da oratória como em suas composiçóes. Já conforme Marcelo Fagerlande (1993, p. 146147, negritos nossos), no seu Methodo de Pianoforte (1821), o padre José Maurício usa das mesmas concepções estéticas e conceituais originárias das doutrinas gregas e latinas de retórica e oratória, embasadas em autores como Aristóteles, Cícero, Quintiliano, Marin Mersenne (1588-1648), Athanasius Kircher e Wolfgang Caspar Printz (1641-1717):

Autores como Aristóteles, Cícero e Quintiliano sugeriam que os oradores usassem os meios retóricos para controlar e direcionar as emoçóes dos ouvintes. Portanto, na música esta ideia correspondia às possibilidades do compositor em mexer com os afetos, emoçóes, do ouvinte. Desde o final do século XVI, os compositores em geral tentam expressar na música (principalmente vocal) os afetos relacionados ao texto, como tristeza, raiva, ódio, alegria, amor e ciúme. A partir de Mersenne e Kircher, na segunda metade do século XVII, muitos teóricos como Werckmeister, Printz, Mattheson, Marpurg, Scheibe e Quantz, dedicaram uma grande parte de seus tratados categorizando e descrevendo tipos de afetos e suas conotaçóes com escalas, movimentos de dança. Ritmos, instrumentos, formas e estilos. [...] Um dos aspectos das ideias retórico-musicais que ganha importância nos tratados tardios são as associaçóes com as tonalidades. [...] Ao compararmos o uso das tonalidades nas obras do Método de Pianoforte com as descriçôes de suas correspondências com os afetos realizados por teóricos como Mattheson (1713) e Christian F. D. Schubart (1806). Podemos afirmar que esta relação entre tonalidades e afeto está também presente nas obras do Método de José Maurício.

Rodrigo Cardoso Affonso (2005) examinou a figura de repetição melódica, Epizeuxis, empregada pelo padre José Maurício nas repetiçóes enfáticas das notas, motivos e da palavra credo. Por fim, Cardoso Affonso (2005, p. 83, negrito nosso) sublinha que, na escrita mauriciana, há uma vinculação sólida entre texto litúrgico e música:

É notável na escrita mauriciana uma forte relação entre texto litúrgico e música. [...] certamente, os estudos e o contato com as partituras musicais (de proeminentes mestres da composiçáo) ao seu alcance e sua intensa vivência musical lhe serviram de tratado vivo e dinâmico de retórica musical. 
Em síntese, inseridos em um contexto no qual as obras musicais, na sua maioria, eram sacras e tinham textos bíblicos repletos de alegorias, metáforas relacionadas à harmonia, contraponto e afeto, muitos dos compositores brasileiros da época se mostraram seguidores da transmissão doutrinária dos sábios mestres da Retórica, da Oratória e da Poética.

\section{ConsideraÇóEs Finais}

Como enfatizado ao longo do artigo, a retórica, desde os primórdios da Antiguidade greco-romana, foi aplicada em consonância a diversos campos do conhecimento. Logo, ela se faz presente no direito, na filosofia, na oratória, na dialética, na literatura, na teologia, na hermenêutica, nas ciências e nas artes, comprovando, desse modo, sua interdisciplinaridade. Além disso, a retórica apresenta-se como instrumento argumentativo, o qual se localiza em diversas epistemologias, dentro de um processo discursivo. Essas epistemologias, por exemplo, estão engendradas e associadas com as transformaçôes no sentido da música, seja nas estruturas de linguagem, seja nos processos de recepção.

Cônscios dessa abrangência, diversos autores, teóricos, tratadistas e pensadores da retórica musical, da transição do Renascimento até o começo do Classicismo, apresentaram um modelo sistematizado e teorizado, fundamentado nos postulados das auctorite da Retórica, da Filosofia e da Poética Clássica - Aristóteles, Cícero e Quintiliano - estabelecendo, dessa forma, a nomenclatura conhecida como Musica Poetica. Decorrente dessa metodização, vários tratados ressaltavam os procedimentos para que a música pudesse ser elaborada num discurso organizado e ordenado por elementos retóricos, objetivados a mover os afetos do ouvinte.

Seguidores desses preceitos, os compositores da música colonial brasileira, tais como Manuel Dias de Oliveira, José Joaquim Emerico Lobo de Mesquita, André da Silva Gomes e José Maurício Nunes Garcia, empregavam os elementos retóricos com o propósito de atrair a atenção do ouvinte, mediante a eloquência e a persuasão. Para isso, certos mecanismos, tais como as figuras retóricas, serviram de auxílio a fim de que esses autores não só pudessem organizar, mas também ordenar o enunciado musical e valorar as cadências, harmonia, repetiçôes, na ênfase das palavras, frases e, por fim, nos afetos trabalhados diligentemente, com a finalidade de mover os sentimentos do público. Melhor dizendo, esse recurso se afigura eficaz, numa composição 
engenhosa, inter-relacionada com variadas partes estruturais, semânticas, textuais e motívicas.

Em síntese, este artigo procurou examinar todo esse processo, a começar do curso desses conhecimentos, passando por suas utilizaçóes até desembocar na formulação epistemológica da retórica, tendo como ferramentas importantes, além da Música, a Filosofia e a Hermenêutica.

SOARES, E. A.; RICCIARDI, R. R. The interdisciplinarity of rhetoric and its influence in colonial Brazilian music. Trans/form/ação, Marília, v. 44, n. 4, p. 157-192, Out./Dez., 2021.

\begin{abstract}
In certain music of the late sixteenth century to early nineteenth century, rhetoric shows itself as an indispensable component for its use, combined with grammar, as well as its adjustment in the musical structures of the time, to be understood and clarified within the musical statement. This process went through a systematization and theorization improved by several authors whose postulate was based on the masters of Classical Rhetoric, thus establishing a terminology known as Musica Poetica. Resulting from this methodology, several treatises highlighted the means by which music could be elaborated in a discourse organized and ordered by rhetorical elements aimed at eliciting and moving the affections of the listener. In this regard, the field of Music through musicology, performance and theory-analysis, in the last fifty years, has been showing interest in the subject developing countless researches through new analytical means, aimed at clarifying the relationship between music and affection. Therefore, this article intends to examine the use of rhetoric to dialogue with other areas of human knowledge, namely, Music, Philosophy and Hermeneutics, besides its influence and use in the Brazilian colonial music by some composers.
\end{abstract}

Keywords: Rhetoric. Philosophy and hermeneutic. Brazilian colonial music. Brazilian composers.

\title{
REFERÊNCIAS
}

ABBAGNANO, N. Dicionário de Filosofia. Tradução de A. Bosi. 2. ed. São Paulo: Martins Fontes, 1998.

ABBAGNANO, N. Dicionário de Filosofia. Tradução de A. Bosi. Revisão de I. C. Benedetti. Edição Revisada e Ampliada. São Paulo: Martins Fontes, 2007.

AFFONSO, R. C. Um Estudo sobre a Relaçáo Texto-Música: os Ofícios Fúnebres de José Maurício Nunes Garcia. 2005. 156 f. Dissertação (Mestrado em Música) - Programa de Pós-Graduação em Música, Centro de Letras e Artes, Universidade do Estado do Rio de Janeiro (UNIRIO), Rio de Janeiro, 2005. 
ARISTÓTELES. Ética a Nicômaco. Tradução de L. Vallandro e G. Bornheim. São Paulo: Abril Cultural, 1984 (Coleção Os Pensadores v. IV).

ARISTÓTELES. Retórica. Prefácio e Introdução de M. A. Júnior, Tradução e Notas de M. A. Júnior, P. F. Alberto e A. N. Pena. 2. ed. Lisboa: Centro de Filosofia da Universidade de Lisboa, Imprensa Nacional-Casa da Moeda, 2005.

ARISTÓTELES. Arte Retórica e Arte Poética. Tradução de A. P. Carvalho. Rio de Janeiro: Ediçôes de Ouro, s/d.

ASSUMPÇÃO, S. E. M. Ascendência Retórica das Formas Musicais. 2007. 141 f. Dissertação (Mestrado em Música) - Programa de Pós-Graduação em Música, Escola de Comunicações e Artes, Universidade de São Paulo (USP), São Paulo, 2007.

BARTEL, D. Musica Poetica: Musical-Rhetorical Figures in German Baroque Music. Lincoln and London: University of Nebraska Press, 1997.

BARTHES, R. Investigaciones retóricas I: La antigua retórica (1970). Tradução de B. Dorriots. Barcelona: Ediciones Buenos Aries, 1982 (Serie Comunicaciones).

BERISTÁIN, H. Diccionário de Retórica y Poética. 7. ed. México: Universidade Nacional Autônoma do México; Porrua, 1995.

BLUTEAU, R. Vocabulario Portuguez e Latino (v.7-letras Q-S). Lisboa: Officina de Pascoal da Sylva, Impressor de Sua Magestade, 1720.

BUELOW, G. Rhetoric and Music. In: SADIE, S.; TYRRELL, J. (ed.). The new grove dictionary of music and musicians. New York: Oxford University Press, 2001. v. 21, p. 260-275.

CÍCERO, M. T. De inventione: De optimo genere oratorum topica. Tradução de H. M. Hubbell, Loeb Classical Library, Harvard University Press, 1960.

CÍCERO, M. T. De Oratore. 4. ed. Cambridge: Harvard University Press, 1967. CÍCERO, M. T. Retórica a Herênio. Tradução e Introdução de A. P. C. Faria e A. Seabra. São Paulo: Hedra, 2005. (Autoria atribuída a Cícero).

COSTA, R. B. O Baixo contínuo no “officio de defuntos” de Lobo de Mesquita. 2006. 172 f. (Dissertação em Música) - Programa de Pós-Graduação da Escola de Música da Universidade Federal de Minas Gerais (UFMG). Belo Horizonte, 2006.

DOTTORI, M. Ut Rhetorica Musica: análise do moteto $O$ Vos Omnes a dois coros, de Manoel Dias de Oliveira. Revista Música, São Paulo, v. 3, n. 1, p. 53-69, maio 1992.

DUPRAT, R. et al. A Arte Explicada de Contraponto de André da Silva Gomes. São Paulo: Arte \& Ciência, 1998.

FAGERLANDE, M. O Método de Pianoforte de José Maurício Nunes Garcia. 1993. 218 f. Dissertação (Mestrado em Musicologia) - Conservatório Brasileiro de Música, Rio de Janeiro, 1993. 
FERREIRA, A. B. H. Novo Dicionário da Língua Portuguesa. 3. ed. Curitiba: Positivo, 2004.

GADAMER, H. G. Verdad y Método II. Salamanca: Sígueme 1992.

HEIDEGGER, M. Ser e Tempo. Tradução de M. S. Cavalcante Schubak. Petrópolis: Vozes, 2005.

HOUAISS, A. Dicionário Houaiss da Língua Portuguesa. Rio de Janeiro: Objetiva, 2001.

JAPIASSÚ, H.; MARCONDES, D. Dicionário Básico de Filosofia. 3. ed. Rio de Janeiro: Jorge Zahar, 2001.

LANGE, F. C. História da Música na Capitania Geral das Minas Gerais: Vila do Serro do Frio e Arraial do Tejuco. v. VIII. Belo Horizonte: Conselho Estadual de Cultura de Minas Gerais,. 1983.

LAUSBERG H. Elementos de Retórica Literária. Tradução, prefácio e aditamentos de R. M. Rosaldo Fernandes. 5. ed. Lisboa: Fundação Calouste Gulbernkian, 2004.

LOPES, R. A tensão mythos-logos em Platão. 2014. 206 f. Tese (Doutorado em Letras, Área de Poética e Hermenêutica) - Faculdade de Letras da Universidade de Coimbra, Coimbra, 2014.

LÓPEZ CANO, R. Música y Retórica en el Barroco. v.1-2. México, D.F: Gráfica da Universidade Nacional Autônoma do México, 2000.

LUCAS, M. I. Material didático da disciplina: CMU 5942 - Introdução à Retórica da Música Setecentista, sob a responsabilidade da Prof. a Dr. ${ }^{a}$ M. I. Lucas. Programa de PósGraduação em Música da Escola de Comunicaçóes e Artes (ECA) da Universidade de São Paulo (USP), São Paulo, 2010.

MARCONDES, D. Iniciaçáo à História da Filosofia: Dos pré-socráticos até Wittgenstein. 6. ed. Rio de Janeiro: Jorge Zahar, 2001.

MATTHESON, J. Der Vollkommene Capellmeister. Fac-simile do original de 1739 (Hamburg: Crsitian Herold). Kassel: Basel: Bärenreiter, 1954.

MATTOS, C. P. José Maurício Nunes Garcia: Biografia. Rio de Janeiro: Biblioteca Nacional, 1997.

MEYER, M. A Retórica. Tradução de M. N. Peres. São Paulo: Ática, 2007.

MORETZSOHN, J. C. R. As Missas de J. J. Emerico Lobo de Mesquita: um estudo estilístico. 2008. 651f. Tese (Doutorado em Música) - Universidade Federal do Estado do Rio de Janeiro, UNIRIO, Rio de janeiro, 2008.

MURPHY, J. J. Sinopsis Historica de la Retórica Clásica. Madrid: Gredos, 1989. 
OLIVEIRA, K. B. A interpretaçáo vocal na Missa em Mi bemol de José Joaquim Emerico Lobo de Mesquita: por uma interpretação historicamente fundamentada, focalizando o solo de soprano quoniam. 2011. 346 f. Dissertação (Mestrado em Música) - Programa de Pós-Graduação em Música, Centro de Letras e Artes, Universidade do Estado do Rio de Janeiro (UNIRIO), Rio de Janeiro, 2011.

PAIXÃO, A. M. M. M. Retórica e Técnicas de Escrita Literária e Musical em Portugal entre os séculos XVII-XIX. 2008. 390 f, v. 1. Tese (Doutorado em Literatura Comparada) - Programa em Estudos Comparatistas da Faculdade de Letras da Universidade de Lisboa em Co-Tutela na Univerisade de Nice Sophia Antipolis (França), Lisboa e Nice, 2008.

PEREIRA, M. B. Retórica, Hermenêutica e Filosofia. Revista Filosófica de Coimbra, v. 3, n. 5, p. 5-70, mar. 1994.

PERELMAN, C. Tratado de Argumentação: A Nova Retórica. Tradução de M. E. A. Prado Galvão. 2. ed. São Paulo: Martins Fontes, 2005.

PERSONE, P. As Obras 'Non Mesurés' para Cravo, Explicadas Segundo as Leis da Retórica. 1996. 160 f. Dissertação (Mestrado em Artes) - Instituto de Artes, IA, Universidade Estadual de Campinas (UNICAMP), Campinas, 1996.

PLEBE, A. Breve História da Retórica Antiga. São Paulo: Editora Pedagógica e Universitária/ EPU, 1978.

QUINTILIANO, M. F. Institutione Oratoria: libri duodecim, cum notis et animadversionibus virorum doctorum. Edição de P. Burmann, revisão e publicação de $\mathrm{P}$. Burmannum, L. Batavorum, apud J. Vivie. Leiden, 1720 [1416].

QUINTILIANO, M. F; HILD, J.A. Instituitione Oratoria: Libri decimus. Paris: C. Klincksieck, 1885 [1416].

REBOUL, O. Introdução à Retórica. Tradução de I. C. Benedetti. 2. ed. São Paulo: Martins Fontes, 2004.

REZENDE, A. M. Rompendo o Silêncio: a construção do discurso oratório em Quintiliano. 2009. 280 f. Tese (Doutorado em Linguística) - Programa de Pós-graduação em Estudos Linguísticos, Universidade Federal de Minas Gerais, UFMG, Belo Horizonte, 2009.

RICCIARDI, R. R. Manuel Dias de Oliveira: um compositor brasileiro dos tempos coloniais - partituras e documentos. 2000. $142 \mathrm{f}+$ anexos. Tese (Doutorado em Artes) Pós-Graduação em Música, Escola de Comunicaçóes e Artes, ECA, Universidade de São Paulo, USP, São Paulo, 2000.

SCATOLIN, A. C. Do orador 1.123-159. Nuntius Antiquus, v. 12, n.2, p. 264-287, jun./dez. 2017. 
SOARES, E. A. A utilização de elementos e figuras de retórica nos Ofertórios de André da Silva Gomes. 2012. 461 f. Dissertação (Mestrado em Música) - PósGraduação em Música, Escola de Comunicações e Artes, ECA, Universidade de São Paulo, USP, São Paulo, 2012.

SOARES, E. A. O Emprego da Retórica na Música Colonial Brasileira. 2017. 533 f. Tese (Doutorado em Música) - Pós-Graduação em Música, Escola de Comunicaçóes e Artes, ECA, Universidade de São Paulo, USP, São Paulo, 2017.

SOARES, E. A. A retórica em quatro compositores da música colonial brasileira: Manuel Dias de Oliveira, José Joaquim Emerico Lobo de Mesquita, André da Silva Gomes e José Maurício Nunes Garcia. Per Musi, v. 39, n. 2, p. 1-31, ago. 2019.

SOARES, E. A; MACHADO NETO, D. Exemplos de Figuras Retóricas de Interrupção e Silêncio em José Joaquim Emerico Lobo de Mesquita. In: SIMPÓSIO INTERNACIONAL DE MÚSICA NA AMAZÔNIA, 4., 2015, Porto Velho. Anais [...] Boa Vista: Editora da UFRR, 2015, p. 363-375.

SOARES, E. A; NOVAES, R; MACHADO NETO, D. Retórica na música colonial brasileira: o uso da anaphora em André da Silva Gomes. In: Encontro de musicologia de Ribeirão Preto, 4., 2012, Ribeirão Preto. Anais [...] Ribeirão Preto: Laboratório de Teoria e Análise Musical, 2012a, p. 301-306.

SOARES, E. A; NOVAES, R; MACHADO NETO, D. Figuras Retóricas no Ofertório da Missa de Quarta-feira de Cinzas de André da Silva Gomes. Música Hodie, v. 12, n. 2, p. 71-86, jun./dez. 2012 b.

VIDAL, J. V. A Idéia do ‘Clássico’ no classicismo: Retórica e Música no Final do Século XVIII. 2002.171 f. Dissertação (Mestrado em Música) - Escola de Música: Centro de Letras e Artes, Universidade Federal do Rio de Janeiro (UFRJ) Rio de Janeiro, 2002.

Recebido: $16 / 4 / 2019$

Aceito: $05 / 8 / 2020$ 